\title{
Partnership Model for the Implementation of Corporate Social Responsibility State own Company in Coastal Community Empowerment Programs in Cilegon City
}

\author{
Rahmawati \\ Public Administration Science \\ Universitas Sultan Ageng Tirtayasa \\ Banten, Indonesia \\ rahmawati@untirta.ac.id
}

\author{
Abdul Apip \\ Governance Science \\ Universitas Sultan Ageng Tirtayasa \\ Banten, Indonesia \\ apip.abdul@gmail.com
}

\begin{abstract}
Cilegon City already has the Cilegon Corporate Social Responsibility (CCSR) Institution which is a mutual agreement between the Cilegon City government and companies in the distribution of corporate CSR. However, the distribution of state-own company CSR to coastal communities has not become a priority. The problem is focused on the form of empowerment given to coastal communities in Cilegon City who are economically categorized as poor families. The purpose of this study is to determine the partnership model for implementing corporate social responsibility from state-owned enterprises in empowering coastal communities in Cilegon City. To approach this problem, the Partnership pattern, according to Wilson, is used. Data were collected through interviews, observations, and literature studies and analyzed qualitatively by case studies. The results showed that the fishermen's group in Cilegon City was already centralized in the location of the fishing bases in Pulo Merak Districts, namely Tanjung Pujut and Kelapa Tujuh, while the fishing bases in Ciwandan were located in Tanjung Leneng. The number of heads of fishing families is 167 people with the education level mostly junior high school. The results also show that the partnership model for implementing CSR in the two regions is also different. CSR partnerships in Ciwandan tend to be counter-productive, where the environmental development funds provided by the company are centralized to NGOs. Assistance for fishermen depends on their proximity to the NGO. The assistance provided is in the form of necessities during the high tide season. Meanwhile, the productive partnership pattern is implemented in Pulomerak Districts through synergy between the sub-districts government where CSR/environmental development funds are directly given to fishermen's families and fishermen in the form of nets, boats, and other fishing equipment, including establishing a fishing base on company land. In addition, food assistance is also provided during the high tide season. The conclusion is that the distribution of CSR
\end{abstract}

funds through CCSR should also touch the coastal communities of Cilegon City.

Keywords-Corporate social responsibility; empowerment; partnership; coastal community.

\section{INTRODUCTION}

The goal of sustainable development or SDGs item 14 is a marine ecosystem that includes the development of the maritime and marine economy and is part of the environmental pillar. Maritime sector development has become the 2015-2019 RPJM. Indonesia as a country that has the second-longest sea area and coastline in the world has several problems and challenges that must be faced. First, the dependence of the community on the sea is still very high, even though of the total population of Indonesia, only about 6 million people are directly involved in fisheries and marine cultivation. Second, there is still management imbalance and a lack of protection of marine and coastal ecosystems in several areas. Third, there is still a high level of illegal fishing and fourth, there is still an imbalance in marine infrastructure which can trigger imbalances in many ways.

The large potential of marine resources has not been optimally utilized by Indonesia, including in this case the coastal community both as fishermen and as users of marine products. The weak position of coastal communities in the management of marine products is one of the causes of poverty in coastal communities, especially fishermen, which is quite high in Indonesia.

BUMN as a government-owned business entity also should carry out environmental or philanthropic development programs in the form of implementing corporate social responsibility. The implementation of a business (business) needs to prioritize social responsibility as a way to balance the interests of 
business and the interests of society without taking government intervention further into the global market space. Business activities are not only for economic gain but must also pay attention to social and environmental interests. Thus, it is necessary to have a concept that is by the interests of business and society, without leaving the interests of the environment, namely by applying the concept of Corporate Social Responsibility (CSR). The application of the CSR concept is expected to be able to achieve commercial success where respect for ethical values and respect for human dignity, community, and the environment is upheld.

Coastal communities as part of the living community in the City of Cilegon need great attention due to their low socio-economic conditions. Some of the coastal areas in Cilegon City are Pulomerak District and Ciwandan District where many stateowned companies have located the area and there are still people who work as fishermen. Pangkalan Kepala Tujuh and Pengkalan Tanjong Pujut are two locations for fishermen in the Pulomerak District to moor their boats and carry out sale and purchase transactions of catches. Meanwhile, the fishing base in Ciwandan District is located in Tanjung Leneng. Based on observations it is known that the average gross income per day of fishermen in Ciwandan District is sixteen thousand four hundred and fifty rupiahs (Rp. 116,450) with 3 to 4 dependents. Meanwhile, the average gross income per day of fishermen in Pulomerak District is one hundred and thirty-one two hundred and fifty rupiahs (IDR 131,250) with 3-4 children as dependents.

There is a difference in the number of fishermen's catch in the two coastal areas in Cilegon City, for Ciwandan fishermen, the catch reaches 3-5 kilograms in a day, while those in Pulomerak produce a larger catch in one day, namely $10-15$ kilograms. This is based on the reach of the fishermen's sea area when fishing. And the tools used to catch fish are still very simple, only a hand-held fishing rod. In one year there are three to four months fishermen do not go to sea due to weather factors and in one month there are one to two weeks fishermen do not go to sea. This is one of the causes of poverty problems in coastal communities, especially fishermen in Cilegon City.

Cilegon City as an industrial, trade and service area has synergized regional development programs through partnerships with companies in the City of Cilegon. The partnership between the company's CSR program and government development programs, which is stipulated in the Cilegon Mayor Regulation Number 3 of 2011, concerning the Establishment of the Cilegon Corporate Social Responsibility (CCSR) Organization and Work Procedure in Cilegon City.

\section{THEORY REVIEW}

CSR is a company or business world commitment to contribute to sustainable economic development by paying attention to corporate social responsibility and emphasizing the balance between attention to its economic, social, and environmental aspects [1].

The uniqueness of CSR is that this activity is very local and indigenous because its implementation must involve local issues and the participation of local communities around the company. The problem of poverty in addition to appearing with its global characteristics also appears with all forms of localization, such as the level of adaptation of local communities to change[2].

Therefore, in this regard, to stimulate the growth of CSR which can encourage sustainable economic development, three main pillars are needed to make it happen [3]. Looking for an effective form of CSR to achieve the expected goals by taking into account the elements of locality; Calculating the capacity of human resources and institutions to stimulate the implementation of CSR; and Regulations and code of ethics in the business world; To realize the three main pillars above requires harmonious cooperation between the government as the policyholder, the company as the financial responsibility for CSR, and the community as the empowered party.

Meanwhile, according to Kamus Besar Bahasa Indonesia, the meaning of the word partner is friend, colleague, colleague. Meanwhile, partnership means a relationship or collaboration as a partner. Hafsah explained that the notion of partnership is a business strategy carried out by two or more parties within a certain period to gain mutual benefits with the principle of mutual need and mutual growth [4]. Because it is a business strategy, the success of the partnership is largely determined by the compliance among those who are partners in implementing business ethics.

According to Wibisono [5], the partnership between the company and the government or community/community can lead to three patterns, namely:

- Counter-productive partnership pattern. This pattern will occur if the company is still based on the conventional pattern which only prioritizes the interests of shareholders, namely pursuing the maximum profit. The focus of the company's attention is indeed more on how the company can make maximum profit, while the relationship with the government and community or society is just a sweetener. The company runs on its target, the government also doesn't care, while the community doesn't have any access to the company. This relationship only benefits a few individuals, for example, unscrupulous government officials or 
thugs in the community. Usually, the costs incurred by the company are only used to maintain certain people. It is understood that for companies what is important is security in the short term.

- Semi-productive Partnership Patterns. In this scenario, the government and community or society are considered as objects and problems outside the company. The company does not know about government programs, nor does the government provide a conducive climate for the business world and the community is passive. This partnership pattern still refers to short-term interests and has not or does not create a sense of belonging on the part of the community and low benefits on the part of the government. Cooperation puts forward the charitable or public relations aspects, where the government and the community or society are still considered more as objects. In other words, the partnership is still not strategic and still prioritizes the company's self-interest, not the common interest between the company and its partners.

- Productive Partnership Patterns. This partnership pattern places partners as subjects and in the common interest paradigm. The principle of symbiosis mutualism is very thick in this pattern. The company has high social and environmental concerns, the government provides a conducive climate for the business world and the community provides positive support to the company. It could even be that partners are involved in a resourced-based partnership pattern, where partners are allowed to become part of shareholders. For example, partners acquire shares through the stock ownership program.

\section{RESEARCH METHOD}

A qualitative approach is suitable for this writing because with this approach a description of the experiences of the phenomenon under study can be generated. Descriptive analysis of events, processes, and meanings is needed to explain how the partnership/partnership strategy is in implementing CSR in Cilegon City. The writer is the main instrument that physically relates to a person, setting, location, or institution to observe or record behavior in its natural setting. The research informants consisted of elements from the local / sub-district government, the CSR / public relations division of BUMN in Cilegon City, and coastal communities (fishermen) in Pulomerak and Ciwandan Districts.

\section{RESULT AND DISCUSSION}

As a city located on the western tip of the island of Java, Cilegon City is the main gate that connects the island of Java with Sumatra. With an area of 175.5
$\mathrm{Km} 2$, which means 1.82 percent of the land area of Banten Province which covers an area of 9,662.92 $\mathrm{Km} 2$. Cilegon City is divided into 8 (eight) Districts and 43 Kelurahan. 2 sub-districts are located in the coastal areas of Banten and the Sunda Strait, namely Pulomerak and Ciwandan.

In a study on the BUMN Partnership Model in the Application of Corporate Social Responsibility in the Coastal Community Empowerment Program in Cilegon City, the informants that the researcher determined were people who according to the researcher had the information needed in this study. The informants in this study are the implementers of the Corporate Social Responsibility program in empowering coastal communities in the City of Cilegon, stakeholders (all parties) both in the village apartment as facilitators, as well as other parties who support the organizers of the implementation of Corporate Social Responsibility in the coastal community empowerment program, namely the Department of Agriculture. and Food Security in Cilegon City, coastal communities in Kelurahan Kepuh, coastal communities in Kelurahan Suralaya, and Academics Untirta who are observers of CSR issues.

The number of fishermen recorded at the Cilegon City Agriculture and Food Security Service in 2020 is 167 people. The following is an overview of fishermen in Ciwandan and Pulomerak Districts according to age, education level, and the number of children. The majority of fishermen in Cilegon City completed 105 primary school education, 38 completed junior high school education, and 24 graduated from high school education. Meanwhile, the number of children owned by fishing families is $1-2$ people as many as 73 people, 3-4 children as 87 people, and fishermen who have more than 5 children are as many as 7 people.

Cilegon City as one of the industrial cities in Banten Province has 3 industrial areas. Most of the industrial estates in Kota Cilegon are held or managed by Krakatau Steel. One of the drivers of investment into the regions is infrastructure. The development of good infrastructure in the City of Cilegon is the driving force for investment in an area. Cilegon City as a trade and service industry city with an investment growth rate in 2014 reached $55.60 \%$. Most of the industrial activities originated from foreign investment companies (PMA) of 130 companies and domestic investment (PMDN) of 39 companies. The investment growth in Cilegon City until 2014 reached 127.79 trillion, consisting of 18.22 trillion PMDN, and IDR 109.57 trillion PMA. The economic structure of Cilegon City depends on the processing industry sector. In 2014, investment realization in Cilegon City through business permits and expansion of PMA amounted to $\mathrm{Rp} 45.47$ trillion and PMDN amounted to Rp 0.35 billion. 
The following are the results of field findings regarding the BUMN partnership model in implementing CSR in the coastal community empowerment program in the City of Cilegon. Capital Issues for Fishermen and Coastal Fishermen Group in Cilegon City Ownership of capital and equipment for fishing groups can be used as a reference for BUMN in providing Corporate Social Responsibility (CSR) for coastal communities, in this case, the fishermen group. Based on interviews with fishermen in both Ciwandan and Pulomerak Districts, it can be seen that the capital and all equipment used for fishing are private property. There is no CSR from BUMN that provides business capital loans or equipment assistance for fishermen groups in Cilegon City.

The role of the City Government of Cilegon in empowering coastal communities in the City of Cilegon Ideally, the implementation of CSR is not only carried out by the corporations themselves but there needs to be involvement from the government and educational institutions in the hope that the CSR program can run programmatically and sustainably. Regarding the involvement of the Cilegon City government in providing CSR to coastal communities, according to one of the general functions of the Agriculture and Resilience Office, it is stated that the local government assists such as lifting vessels, nets, safety equipment, fishing rods, and providing safety training, boat repair training, repair training fish processing machines and training. Meanwhile, for the provision of corporate CSR to fishermen, it is entirely up to the company to be able to channel it directly to the community around the company as well as to the fishing community. This is following what was conveyed by the head of the PKBL partnership division of PT KS, that CSR is given directly to the community.

Forms of cooperation are carried out by urban village governments with BUMN in implementing CRS in Coastal Areas. Ideally, CSR implementation should involve local officials at least at the district level so that the activities carried out can run programmatically and officially. In the implementation of CSR carried out by BUMN in Cilegon City, as has been done by PT. Indonesia Power involves local officials as said by the Suralaya Urban Village Head that there is coordination or a form of cooperation that exists with the Kelurahan and BUMN in the context of implementing the Corporate Social Responsibility (CSR) program in the coastal community empowerment program in the City of Cilegon, the urban village becomes a facilitator for fishermen groups in Cilegon City with a state-owned company in Cilegon City. From the results of the interview, Kelurahan Kepuh and Kelurahan Suralaya became the parties that provided the legality of the permit for the request for assistance submitted by the Fishermen Group to the company.
Forms of Corporate Social Responsibility (CSR) are provided by BUMN to coastal communities in the City of Cilegon. Based on field findings, there are differences in the company's CSR assistance in empowering coastal communities in Cilegon City. PT. Indonesia Power, which is located in Pulomerak Subdistrict, assisted services by making land belonging to Indonesia Power as a fishing base for the Suralaya service groups, in addition to fishermen families also provided basic food assistance. In addition, Suralaya fishermen have also applied for paving blocks and the installation of sloping stone foundations around the Suralaya fishermen's base has also been carried out. A different thing happened to fishermen in Ciwandan Subdistrict, where the CSR program of PT KS Group was mostly in the form of providing basic foodstuffs to fishermen's families.

Referring to the partnership model in implementing CSR in the City of Cilegon, it can be seen that the Counter-Productive Partnership Model occurs when the company is still based on conventional wisdom which only prioritizes the interests of shareholders, namely pursuing maximum profit. The focus of the company's attention is indeed more on how the company can make maximum profit, while the relationship with the government and community or society is just a sweetener. The company runs on its target, the government also doesn't care, while the community doesn't have any access to the company. This relationship only benefits a few individuals, for example, unscrupulous government officials or thugs in the community. Usually, the costs incurred by the company are only used to maintain certain people. It is understood that for companies what is important is security in the short term.

Based on the results of observations and interviews, it is known that there is a counterproductive partnership pattern, in which CSR funds are handed over to NGOs or community organizations located in an industrial area in the City of Cilegon. CSR funds from several companies in area $\mathrm{x}$ are managed by the community-owned organization FIKS. The CSR funds that are delegated to the NGO's authority are included in the distribution to the community. The villagers in area $\mathrm{x}$ themselves do not know and understand the existence of this organization / NGO. When the community submitted a proposal to request assistance from CSR funds, the company had submitted it to the NGO and the company did not know what activities and who received assistance from the company's CSR in area X because CSR funds were fully managed by the organization. The public suspects the existence of the organization on the grounds of maintaining company security. The use of these funds and their responsibility is more informal. And related to the empowerment of fishermen who live in the area, they do not get any capital assistance or assistance from the CSR funds of companies in 
region $\mathrm{x}$. Fishermen who are in area $\mathrm{x}$, all of their business capital comes from individuals. Needles, bait, fuel, and boats are all private capital obtained by borrowing from fishermen bosses in area $\mathrm{x}$.

The Productive Partnership Model places partners as subjects and in the common interest paradigm. The principle of symbiosis mutualism is very thick in this pattern. The company has high social and environmental concerns, the government provides a conducive climate for the business world and the community provides positive support to the company. It could even be that partners are involved in a resourced-based partnership pattern, where partners are allowed to become part of shareholders. For example, partners acquire shares through the stock ownership program.

In the productive partnership model, companies in the City of Cilegon have already done it, including state-owned companies. In this case, the BUMNs highlighted are PT Krakatau Steel and PT Indonesia Power. Partnership model in implementing CSR of PT. Indonesia Power as a state-owned company in Cilegon City with the community is not only providing basic foodstuffs but also facilities that support the Suralaya Fishermen Group, such as providing a fishing base, renovating the fishing base road, and installing a sloping stone foundation at the fisherman's base.

Meanwhile, the partnership model for implementing CSR by PT Kratakau Steel has not yet touched the lives of coastal communities. The CSR provided by BUMN KS is limited to providing basic foodstuffs, but nothing is about empowering coastal communities in the City of Cilegon. This can be analyzed with the zoning of the area provided for CSR by PT Krakatau Steel through its PKBL, that the coastal community area of Cilegon City is in zone 2 of the CSR program of PT. KS. Although it does not provide direct assistance in the form of boats or nets to fishermen, PT KS provides basic foodstuffs to fishermen during the low season or when the fishermen are not at sea/fishing.

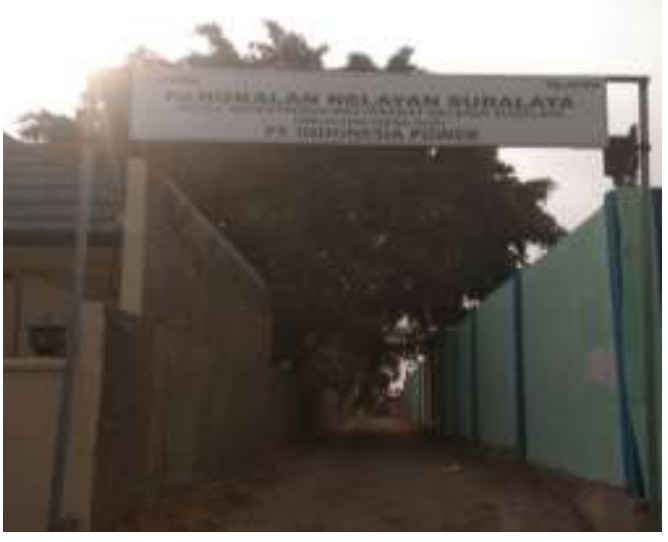

Fig. 1. Fishing base at suralaya Pulomerak

The provision of CSR funds to the people of Cilegon City itself has not or has not been specified for the community or fishermen groups. Through the CCSR institution, the companies that are members of it, routinely carry out activities to provide assistance as attached in the table below.

TABLE I. CSR FUNDS CHANNELED THROUGH CCSR INSTITUTIONS 2011-2013

\begin{tabular}{|c|c|c|c|c|}
\hline Year & Program activity & Target & Progress & Sponsor/company \\
\hline \multirow[t]{5}{*}{2011} & $\begin{array}{l}\text { Package Books for middle and } \\
\text { high school }\end{array}$ & 129.450 & 129.450 & $\begin{array}{l}\text { BJB, PT Krakatau Steel, PT } \\
\text { Chandra Asri, Forum BUMD }\end{array}$ \\
\hline & $\begin{array}{l}\text { Districts-based Community } \\
\text { Economic Empowerment }\end{array}$ & $8 \mathrm{M}$ & $1,5 \mathrm{M}$ & Pemkot Cilegon, PT Krakata Steel \\
\hline & Family latrines & 200 target household & 198 target household & $\begin{array}{l}\text { PT. KS, PT Chandra Asri dan Bank } \\
\text { BJB }\end{array}$ \\
\hline & Electricity for community & 7258 target household & - & PT. Indonesia Power \\
\hline & $\begin{array}{l}\text { Restoration of uninhabitable } \\
\text { houses }\end{array}$ & 50 target household & 44 target household & Bank BJB \\
\hline \multirow[t]{6}{*}{2012} & $\begin{array}{l}\text { Package Books for elementary } \\
\text { school }\end{array}$ & 72.237 books & 72.237 books & $\begin{array}{l}\text { BJB, PT Krakatau Steel, PT } \\
\text { Chandra Asri, Forum BUMD }\end{array}$ \\
\hline & Family latrines & 400 target household & 330 target household & $\begin{array}{l}\text { PT. KS, PT Chandra Asri dan Bank } \\
\text { BJB }\end{array}$ \\
\hline & $\begin{array}{l}\text { Restoration of uninhabitable } \\
\text { houses }\end{array}$ & 50 & 35 & Bank BJB \\
\hline & $\begin{array}{l}\text { Glasses assistance for elementary } \\
\text { school students }\end{array}$ & 200 & 117 & $\begin{array}{l}\text { PT. Indonesia Power } \\
\text { PT. Chandra Asri }\end{array}$ \\
\hline & Proyantek development & 8 districts & 8 districts & $\begin{array}{l}\text { PT. Indonesia Power } \\
\text { PT. Mitsubishi } \\
\text { PT. ASDP Merak } \\
\text { PT. Chandra Asri }\end{array}$ \\
\hline & Electricity for community & 200 target household & 100 target household & PT. Indonesia Power \\
\hline \multirow[t]{2}{*}{2013} & Family latrines & 350 target household & 95 target household & $\begin{array}{l}\text { PT. Krakatau Steel, PT. Chandar } \\
\text { Asri, PT Indonesia Power } \\
\text { PT Wijaya Karya }\end{array}$ \\
\hline & Electricity for community & 1200 target household & 300 target household & PT Indonesia Power \\
\hline
\end{tabular}




\begin{tabular}{|l|l|l|l|l|}
\hline \multirow{2}{*}{$\begin{array}{l}\text { Restoration of uninhabitable } \\
\text { houses }\end{array}$} & 450 & 10 & $\begin{array}{l}\text { PT. Krakatau Steel } \\
\text { PT. ASKES }\end{array}$ \\
\cline { 2 - 5 } & Wastes Bank & 8 districts & 3 districts & PT. Chandra Asri \\
\cline { 2 - 5 } & $\begin{array}{l}\text { Glasses assistance for elementary } \\
\text { school students }\end{array}$ & 150 & 120 & $\begin{array}{l}\text { PT. Indonesia Power } \\
\text { PT. Chandra Asri }\end{array}$ \\
\cline { 2 - 5 } & $\begin{array}{l}\text { Dialysis for poor people by } \\
\text { Jamkesda }\end{array}$ & 13 people & 13 people & Bank BJB \\
\hline
\end{tabular}

\section{CONCLUSION}

The partnership model in implementing CSR in Cilegon City has different characteristics, but all of them aim to help fishermen who experience catch problems when they are not at sea. It is hoped that the partnership that will be carried out further emphasizes efforts to increase the ability of fishermen by providing training, financial/capital assistance, and equipment as well as new entrepreneurial assistance as a solution when catches decrease.

\section{ACKNOWLEDGMENT}

Thank you to all the research informants, namely fishermen, local government elements, the person in charge of CSR BUMN, the rector of Untirta, Dean of FISIP, and to my beloved husband and children.

\section{REFERENCES}

[1] Suhandari M. Putri, CSR Scema, Kompas, 4 August 2007.

[2] Hendrik Budi Untung, Corporate Social Responsibility, first printing, Sinar Grafika, Jakarta, 2008.

[3] Dyah Pitaloka, 2007. Strengthening CSR to Eradicate Poverty, Suara Merdeka, August 2, 2007.

[4] Hafsah, M Jafar. 1999. Business Partnership. Pustaka Sinar Harapan, Jakarta

[5] Wibisono, Yusuf. 2007. Dissecting the Concept and Application of CSR. Fascho Publishing. Gresik

[6] Rahmatullah. 2012. The Government-Company Partnership Model in Managing CSR. Case Study in Cilegon City. Journal of Information. Vol 17 No. 01 of 2012. 